\title{
9. OOLITIC LIMESTONE ON THE ITA MAITAI GUYOT, EQUATORIAL PACIFIC: DSDP SITE 202
}

\author{
The Shipboard Scientific Party ${ }^{1}$
}

\begin{abstract}
SITE DATA
Occupied: $28-30$ Oct 1971

Position: Summit of Ita Mai Tai Guyot, near eastern edge; lat $12^{\circ} 48.9^{\prime} \mathrm{N}$

long $156^{\circ} 57.2^{\prime} \mathrm{E}$

Water Depth: 1505 meters

Number of Cores: 6

Total Penetration: 153.5 meters

Deepest Unit Recovered: Carbonate mud of unknown age.

Main Results: The basement-like reflector which lies beneath the early Eocene globigerina sandstone is a hard oolitic limestone deposited as the former island was submerged. The underlying calcareous mud, which contains coral debris, apparently is a lagoon deposit and suggests that a fringing reef existed at the time of deposition. Small fragments of basalt and feldspar crystals were found in the ooze, suggesting that the volcanic pedestal was not completely buried during the Tertiary and that the guyot had never become an atoll before it sank.
\end{abstract}

\section{OPERATIONS}

The ship steamed eastward from Site 201 across the flat summit of Ita Mai Tai Guyot to the steep eastern flank. Near the eastern edge, a thickness of upper transparent layer of about 70 meters was noted on the profiler, and a preliminary interpretation of the profile suggested that the lower part of the transparent layer might be extremely thin or missing. The ship's course was reversed and the beacon dropped at 1030 on 28 October. The first beacon was dropped before the site was reached; a second beacon failed, and, finally, a third beacon was dropped and became operational over the previously selected location. The location of Site 202 and bathymetry are shown on Figures 1 and 2, respectively, and seismic profiles across the site are shown on Figures 3 and 4.

Hole 202 was spudded-in at 2025 on 28 October; the bit was washed-in to 49 meters, where Core 1 was taken (Table 1). It consisted of a foraminiferal sand similar to that obtained at Site 200 . The second core was taken immediately above the strong reflector which underlies the

\footnotetext{
${ }^{1}$ Bruce C. Heezen, Lamont-Doherty Geological Observatory; Ian D. MacGregor, University of California, Davis; Helen P. Foreman, Oberlin College; George Forristall, Eidgenössische Technische Hochschule, Zürich; H. Hekel, Queensland Geological Survey, Brisbane; Reinhard Hesse, Technische Hochschule, Munich; Robert H. Hoskins, New Zealand Geological Survey, Lower Hutt; E. John W. Jones, University College, London; Ansis Kaneps, Scripps Institution of Oceanography, La Jolla; Valeri A. Krasheninnikov, Academy of Sciences, Moscow; Hakuyu Okada, Kagoshima University, Japan; Michael H. Ruef, Washington Department of Ecology, Olympia.
}

winnowed ooze. Core 3 , which took two hours to cut and retrieve (1800-2000 hours), was a hard oolitic limestone. The recovery of Core 3 was so small that Core 4 was cut from 83 to 106 meters, obtaining another sample of oolite. Immediately following Core 4 , drilling rates increased dramatically. Core 5 was cut from 106 to 125 meters and obtained only a small sample of coral mud. Core 6 was cut from 125 to 153.5 meters but was empty when retrieved. During retrieval of Core 6, the string stuck (at 0030 on 19 October) in the hole and could not be extracted. At 2300 on 29 October, the collar locator was run down the pipe. Then the electrical severing charge was sent down, but although the cap fired the charge did not. The electrical severing charge was again sent down and fired, but apparently it severed the pipe below the point where it was stuck. At 1015 on 30 October, the logging cable was pulled out of the hole. The pipe was found to move slightly, and slowly came up several joints until the upper part of the bottom hole assembly was above mud line. Then one stand was added to the string and at 1045 on 30 October the pipe twisted off at the base of the second collar from the top of the assembly. Two bumper subs came aboard and the hole was abandoned at 1600 on 30 October 1971. The ship proceeded to the lee of Kusaie Island for an inspection and possible switch-over of the defective fast-line sheave of the crown block, which had been reported in unsatisfactory condition at the end of Site 199. The ship arrived at Kusaie Island at 1100 on 2 November 1971. While the inspection and change-over were taking place, the scientific staff put ashore on Kusaie and collected basalts, soil samples, beach samples, and clay samples (in the rain). After the inspection from 1200-2015 on 2 November, it was decided by the drilling personnel that the block could safely drill one more hole on the Solomon Rise, in 13,000 feet of water, and the ship proceeded to the selected location. However, it was the judgement of engineers onshore that continued drilling was unsafe, and on 4 November the ship was ordered to proceed directly to Suva.

\section{NATURE OF THE SEDIMENTS}

Site 202 was spot cored to a total depth of 153.5 meters before the drill string stuck and the hole had to be abandoned. Six cores were attempted, the last was recovered empty (Figures 5 and 6 ).

A carbonate sequence was penetrated, comprising 75 meters of Tertiary pelagic foraminiferal ooze (Core 1), which becomes indurated at the base (Core 2). This succession overlies approximately 35 meters of hard oolitic limestone (Cores 3 and 4). Core 5 recovered only a calcareous "milk" consisting of fine-grained coccolith-free carbonate, which may be fragmented coral material. Core 6 was recovered empty so the nature of the sediments and basement underlying the carbonate sequence is unknown. 


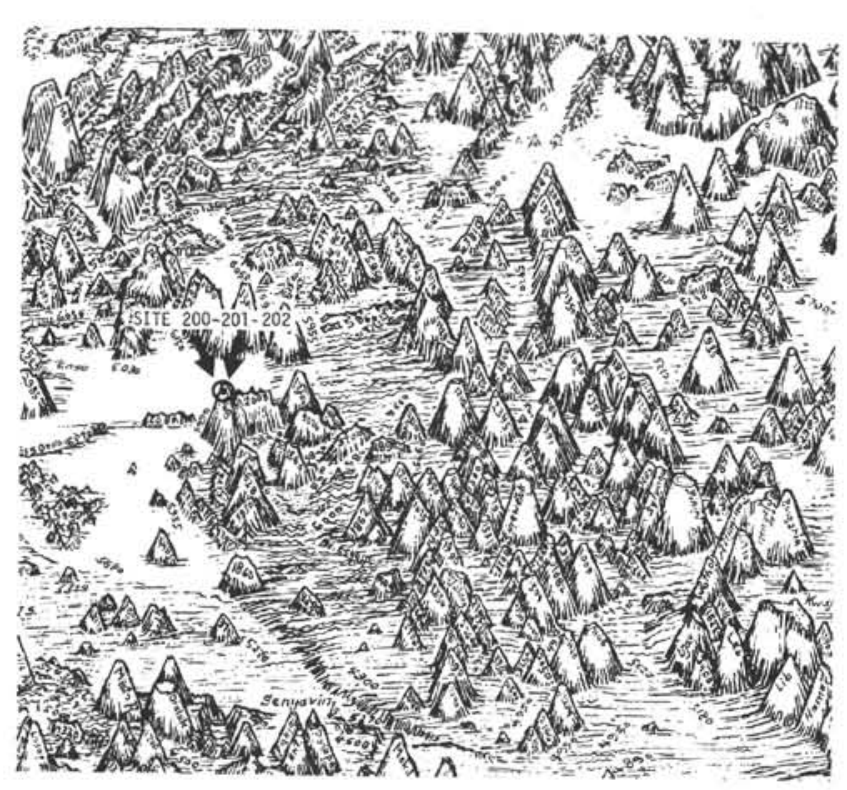

Figure 1. Location of Site 202.

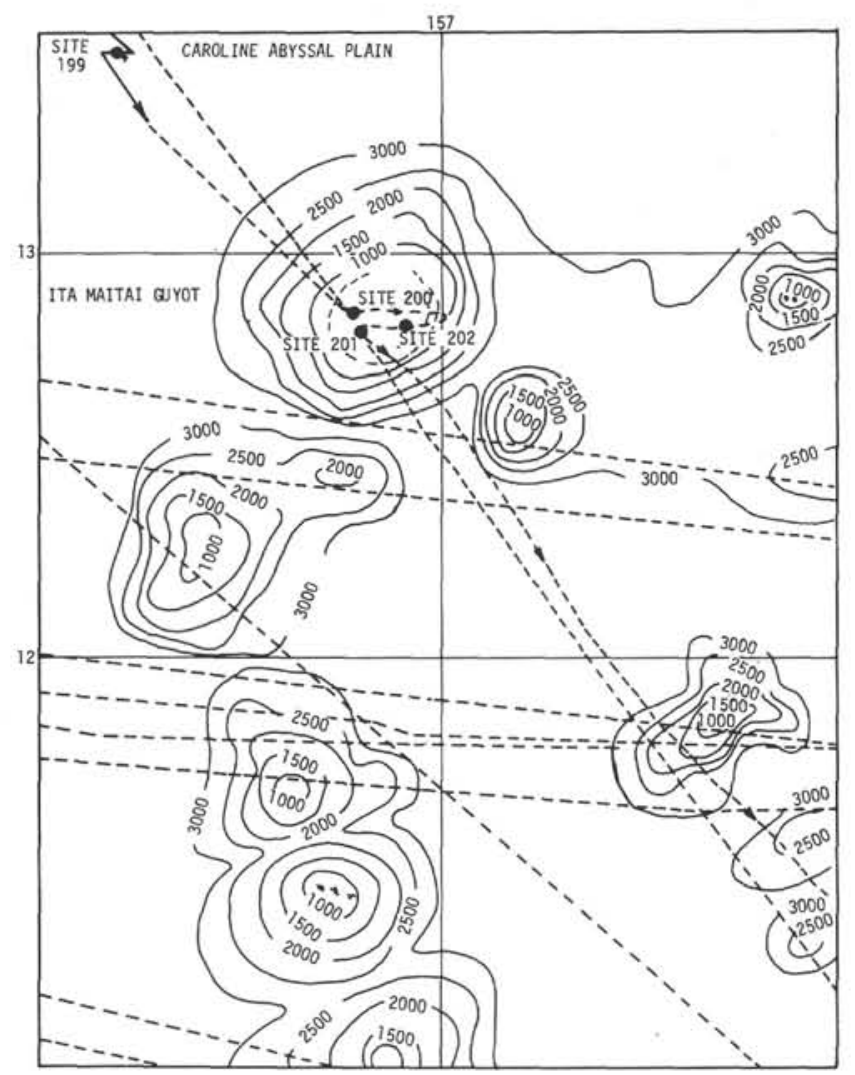

Figure 2. Bathymetry in the vicinity of Site 202 (based on various sounding lines). Contour interval 500 tau (1 tau $=1 / 400 \mathrm{sec}$ ).

\section{Core 1 (49-58.5 Meters)}

This core is made up of unconsolidated, tan colored fairly clean foraminiferal sand in which nannofossils occur as trace constituents. Owing to the watery nature of the core, neither the stratigraphic sequence nor sedimentary structures are preserved. The base of the core is of early Pliocene age.

\section{Core 2 (65-74 Meters)}

This core consists of a core catcher sample of one small fragment of white, indurated foraminiferal ooze of middle Eocene age.

\section{Cores 3 and 4 (74-106 Meters)}

These cores recovered $45 \mathrm{~cm}$ (Core 3 ) and $35 \mathrm{~cm}$ (Core 4) of $\tan$ oolitic limestone. The rock is generally lithified, although in spots incomplete cementation results in a porous texture. The rock is massive in appearance and is lacking in sedimentary structures such as lamination, cross-bedding, or bioturbation structures. The oolitss are well sorted and range from 0.5 to $1 \mathrm{~mm}$ in diameter. In section they display the typical structure of concentric shells of micrite of various shades of tan to brown.

The upper $10 \mathrm{~cm}$ of Core 3 are of a grayish shade that gradually disappears downwards. This possibly indicates that the top of the oolite layer was cored and that the top may be unconformable with the overlying pelagic ooze.

No microfossils or nannofossils were found in the oolite. Macrofossils are only sparsely present: Very rare, sand-size shell fragments occur in Core 3 , and rather more common shell and bryozoan fragments and occasional whole specimens of small gastropods, in Core 4. The age of the oolite is undeterrnined.

\section{Core 5 (115.5-125 Meters)}

The only recovery in this attempt was white, calcareous "milk" which consists of silt-size calcite grains of unclear origin. Some of the material may consist of coral fragments.

\section{BIOSTRATIGRAPHIC SUMMARY}

Core 1, CC (49.0-58.5 meters) consists of sand-sized foraminiferal ooze similar to that found in Hole 200 and Core 1, CC of Hole 200A. This ooze contains abundant nannoplankton of the Discoaster asymmetricus Subzone and abundant foraminifera of the Sphaeroidinella dehiscens-Globoquadrina altispira Zone (N.19 of Blow), indicating an early Pliocene age. Extremely rare, wellpreserved Radiolaria of similar aspect to those in Hole 200, Core 1 were found only in Core 1 of Hole 202. No diagnostically significant Radiolaria were recognized.

Abundant, but poorly preserved foraminifera and few moderately preserved nannoplankton were found in the foraminiferal limestones of Core 2, CC (65-74.0 meters), which are middle Eocene in age. Foraminifera typical of the Orbulinoides beckmanni Zone and nannoplankton of the Discoaster saipanensis Subzone were found.

No foraminifera, nannofossils, or Radiolaria were found in the oolitic limestones of Cores 3, 4, and 5 (83.5-153 meters). Traces of coral debris were recognized in Core 5 .

Age and correlation of foraminiferal and nannofossil zones at Site 202 are as follows:

$\begin{array}{llll}\text { 202-1, CC } & \begin{array}{l}\text { Sphaeroidinella dehiscens- Discoaster } \\ \text { Globoquadrina altispira } \\ \text { Zone }\end{array} & \begin{array}{l}\text { Early } \\ \text { assymetricus } \\ \text { Subzone }\end{array} & \text { Pliocene } \\ & & \end{array}$




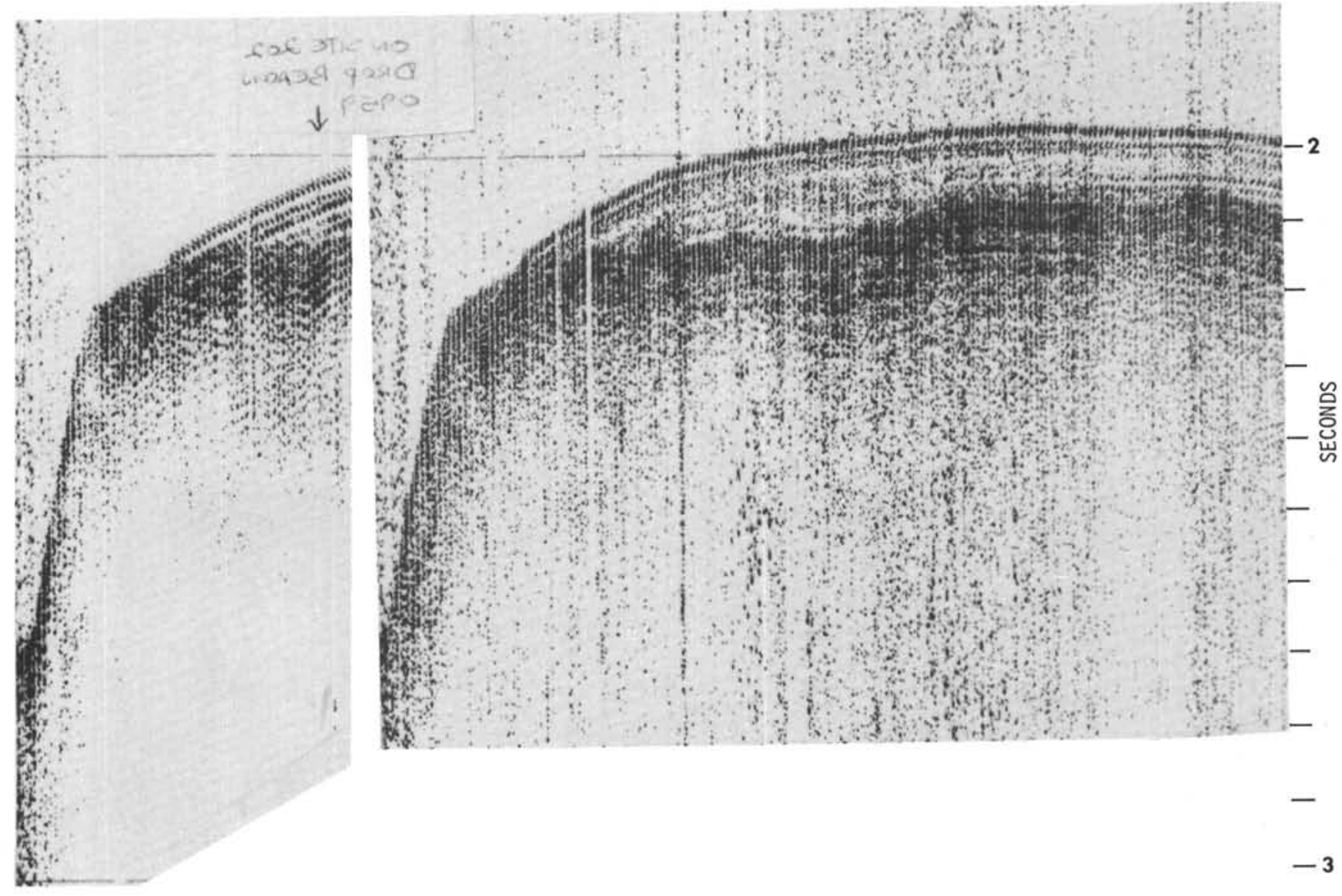

Figure 3. Glomar Challenger seismic profile across Site 202 on site approach.

$\begin{array}{llll}\text { 202-2, CC } & \begin{array}{l}\text { Orbulinoides beckmanni } \\ \text { Zone }\end{array} & \begin{array}{l}\text { Discoaster sai- } \\ \text { panensis } \\ \text { Subzone }\end{array} & \begin{array}{l}\text { Middle } \\ \text { Eocene }\end{array}\end{array}$

Biogenic components found in Site 202 cores are summarized as follows:

\section{Core 1:}

Foraminifera: Abundant Sphaeroidinella dehiscens, Globorotalia tumida, $G$. multicamerata, $G$. humerosa, $G$. crassaformis, Pulleniatina obliquiloculata, Globigerinoides conglobatus, G. rubrum, G. sacculifera, Sphaeroidinellopsis seminulina, Sph. subdehiscens, Globoquadrina dehiscens, G. altispira, Globigerina nepenthes. Lower Pliocene; the Sphaeroidinella dehiscensGloboquadrina altispira Zone (N.19).

Uphole contamination of rare Pleistocene foraminifera-Globorotalia truncatulinoides.

Nannofossils: The age determination of early Pliocene (Discoaster asymmetricus Subzone) would conform with wedging out of the sediments close to the edge of Ita Mai Tai Seamount. The association of nannofossils is rich and similar to Site 200, Core 3. Isolated late Miocene species (Discoaster neohamatus, Discoaster quinqueramus) are interpreted as being reworked.

Radiolaria: Extremely rare, good Radiolaria. No stratigraphically significant species were recognized.
Core 2:

Foraminifera: Abundant planktonic foraminiferaOrbulinoides beckmanni, Hantkenina alabamensis, Globigerinatheka barri, Globigerapsis index, G. kugleri, Globorotalia spinulosa, $G$. centralis, $G$. lehneri, Acarinina bullbrooki, Truncorotaloides topilensis, $T$. rohri, Globigerina peudovenezuelana, G. galavisi, G. pseudoeocaena. Middle Eocene; the Orbulinoides beckmanni Zone (P.13).

Nannofossils: As in Site 200A, Core 2, only a few nannofossils have been recovered from the globigerina sands of this sample. Nevertheless, the Discoaster saipanensis Subzone of the Reticulofenestra umbilica Zone was found, as indicated by the occurrence of Dictyococcites bisectus and Chiasmolithus grandis. Further species are Discoaster nodifer, Cyclococcolithina lusitanica, and Cyclicargolithus floridanus.

Radiolaria: none.

\section{Core 3:}

Foraminifera: none.

Nannofossils: none.

Radiolaria: none.

\section{Core 4:}

Foraminifera: none.

Nannofossils: none.

Radiolaria: none. 


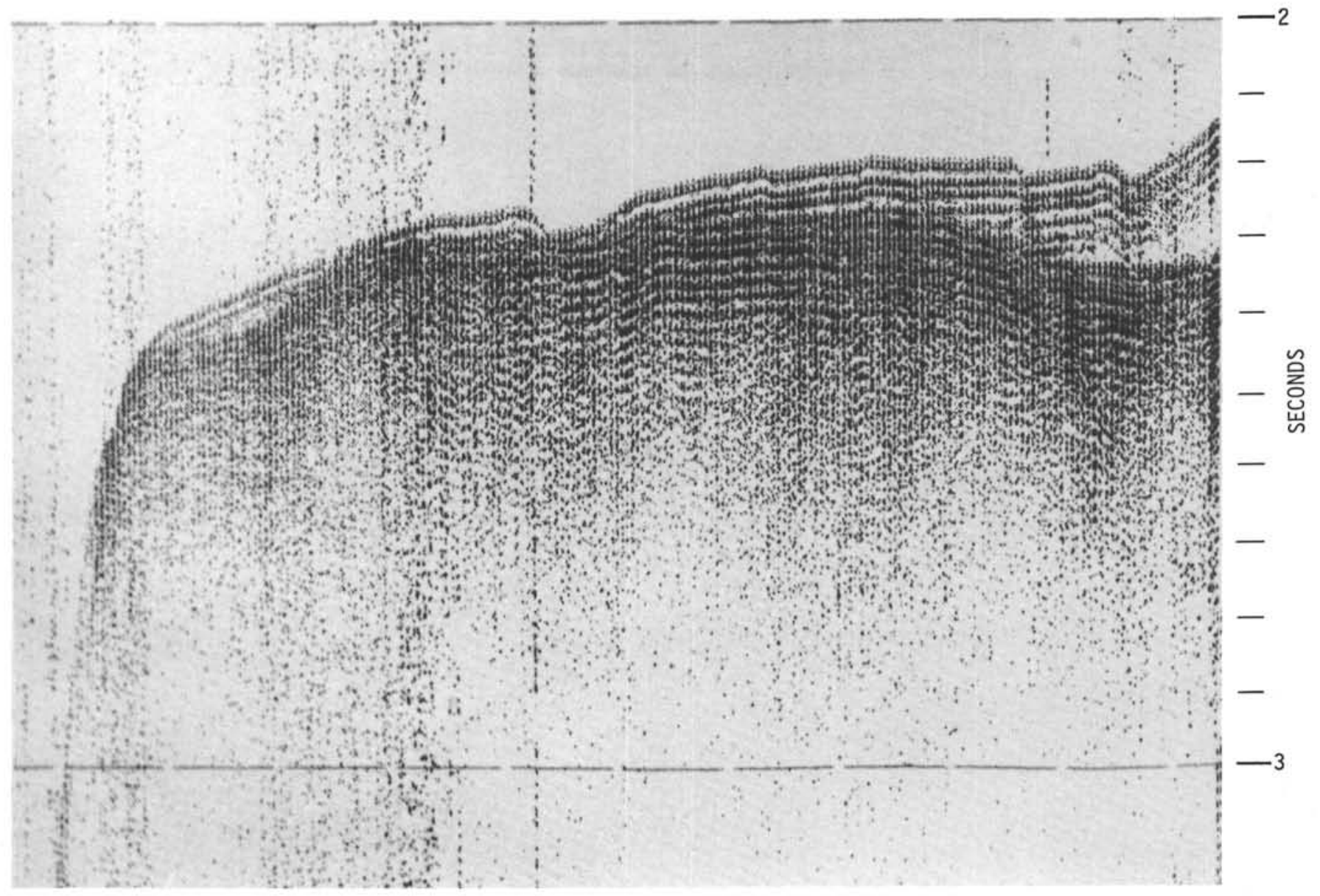

Figure 4. Glomar Challenger seismic profile across Site 202.

\section{Core 5:}

Foraminifera: none.

Nannofossils: none.

Radiolaria: none.

\section{Core 6:}

Foraminifera: none. Nannofossils: none. Radiolaria: none.

\section{PHYSICAL PROPERTIES}

Cores 3 and 4, recovered between 74 and 106 meters subbottom depth at Site 202, contains several pieces of oolite large enough for physical properties measurements.

Despite the coarse-grained appearance of the oolites, they have a relatively high average density of $2.25 \mathrm{gm} / \mathrm{cc}$, which corresponds to a porosity of 0.27 .

Their granular nature made it difficult to get a good contact with the transducer heads for velocity measure-

TABLE 1

Coring Summary, Site 202

\begin{tabular}{|c|c|c|c|c|c|c|c|c|c|c|c|}
\hline \multirow[b]{2}{*}{ Core } & \multirow{2}{*}{$\begin{array}{l}\text { Date } \\
\text { (Oct) } \\
\end{array}$} & \multirow[b]{2}{*}{ Time } & \multicolumn{2}{|c|}{$\begin{array}{l}\text { Subbottom } \\
\text { Depth }(\mathrm{m})\end{array}$} & \multicolumn{2}{|c|}{ Total Depth $(\mathrm{m})$} & \multirow{2}{*}{$\begin{array}{c}\text { Cored } \\
(\mathrm{m})\end{array}$} & \multirow[b]{2}{*}{ Recovered } & \multirow[b]{2}{*}{ Age } & \multirow[b]{2}{*}{ Lithology } & \multirow[b]{2}{*}{ Paleontology } \\
\hline & & & Top & Bottom & Top & Bottom & & & & & \\
\hline 2 & 28 & 1805 & 65 & 74 & 1580 & 1589 & 9 & $\mathrm{CC}$ & Middle Eocene & Globigerina sandstone & Foraminifera \\
\hline 4 & 28 & 2155 & 96.5 & 106 & 1611.5 & 1621 & 9.5 & 0.5 & $?$ & Oolitic limestone & Gastropod shells \\
\hline 5 & 28 & 2325 & 115.5 & 125 & 1630.5 & 1640 & 9.5 & $\mathrm{CC}$ & $?$ & Lime mud & $\begin{array}{l}\text { Biogenetic carbonate } \\
\text { but no nannofossils }\end{array}$ \\
\hline 6 & 29 & 0110 & 144 & 153.5 & 1659 & 1668.5 & 9.5 & 0 & A few Tertiary & oraminifera in clean wat & ter; contamination \\
\hline
\end{tabular}

Note: Mudline is at 1515 meters. 

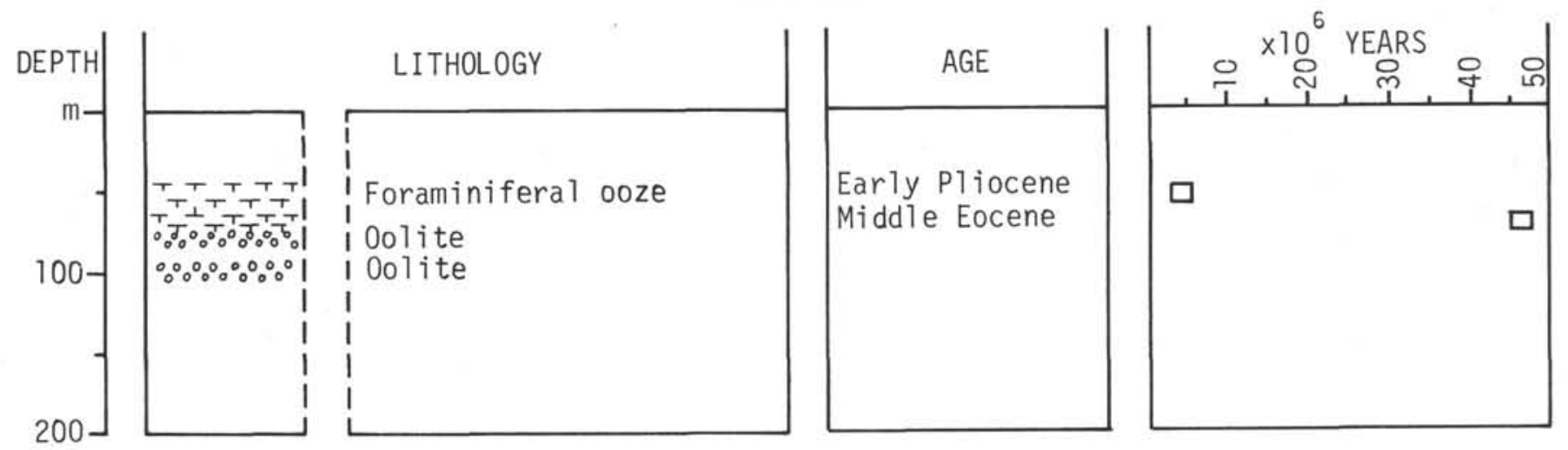

Figure 5. Stratigraphy of Site 202.

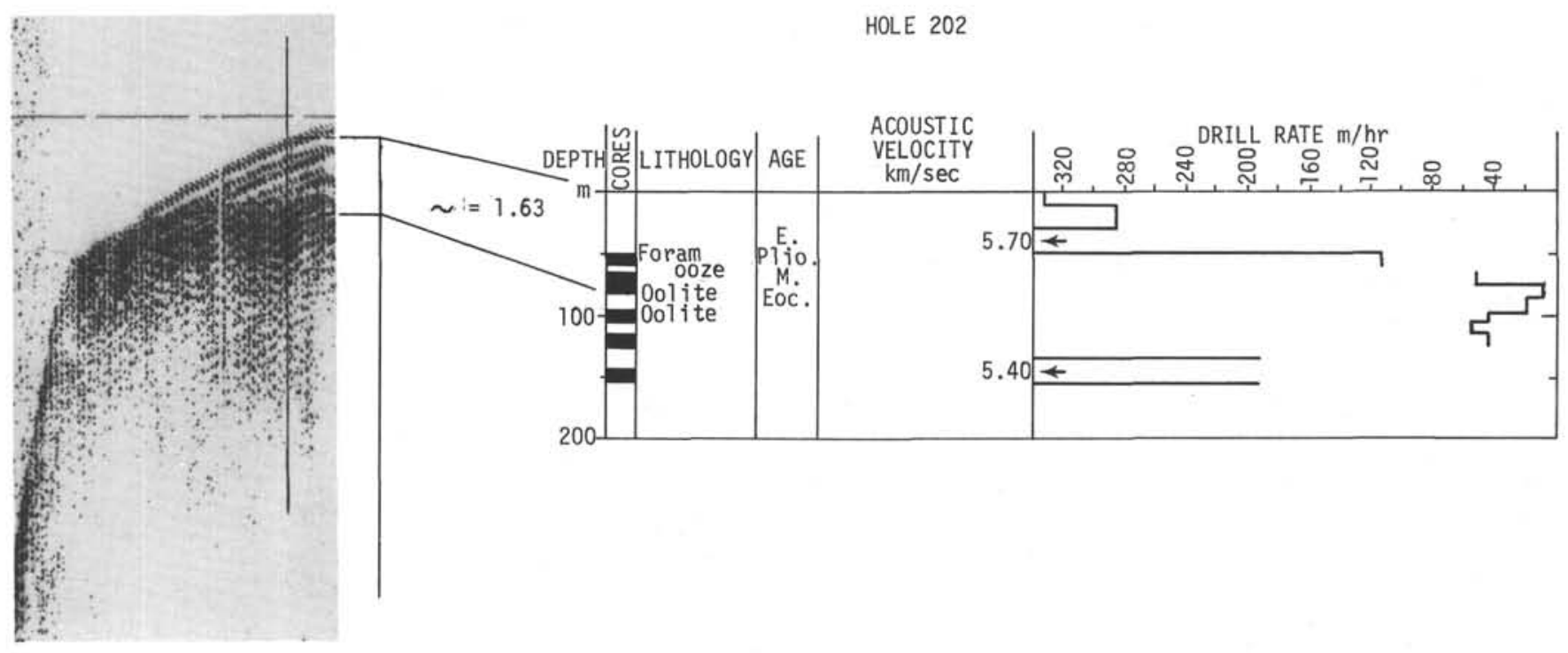

Figure 6. Correlation of drilled record at Site 202 with seismic reflection profile.

ments, a problem which was solved by immersing the sample in water during testing. The sonic velocities thus measured averaged $3.83 \mathrm{~km} / \mathrm{sec}$ with no clear anisotropy.

\section{CONCLUSIONS}

The early Eocene to Recent foraminiferal ooze capping the guyot, although thinner at Site 202 than at Sites 200 and 201 , has nearly the same mechanical properties. The strong acoustic reflector which underlies the winnowed ooze is a 30 - to 40 -meter-thick oolitic limestone. This reflector is so efficient that reflections beneath the oolite are extremely faint. Oolites are assumed to be characteristic of shallow, lime-saturated waters near coral reefs in which continuous, rather vigorous agitation winnows out the fines and constantly rotates the oolites as they grow. Oolites have not been reported as deep-water deposits, and although such an origin cannot be absolutely excluded, it seems most reasonable to accept the oolitic limestone as an indication of lime-reef facies. The oolite is a hard crust over a much softer inside. Only one core of the underlying soft formation was obtained, but this one is highly interesting. The lime mud contains no foraminifera and (most remarkedly) no nannofossils. The mud does contain fine coral fragments and can be interpreted as a near-reef facies, probably lagoonal, rather than an offshore facies, where planktonic fossils should be present. Thus, one can envisage a history of volcanism culminating perhaps in the Campanian or Maastrichtian, as suggested by Hole 199, followed by the growth of fringing reefs on the subsiding foundation.

However, subsidence rates relative to growth conditions were apparently too high for the coral to grow up indefinitely, and after a brief existence, the volcanic island became a coral bank and finally a subsiding guyot, collecting winnowed pelagic ooze.

If we are not permitted to accept the tuff in Hole 199 as evidence of the growth of the pedestal of Ita Mai Tai Guyot, then we have no constraint on its age, and it is quite possible to assume that it had an existence as an atoll before its demise for unknown reasons in the pre-early Eocene. 


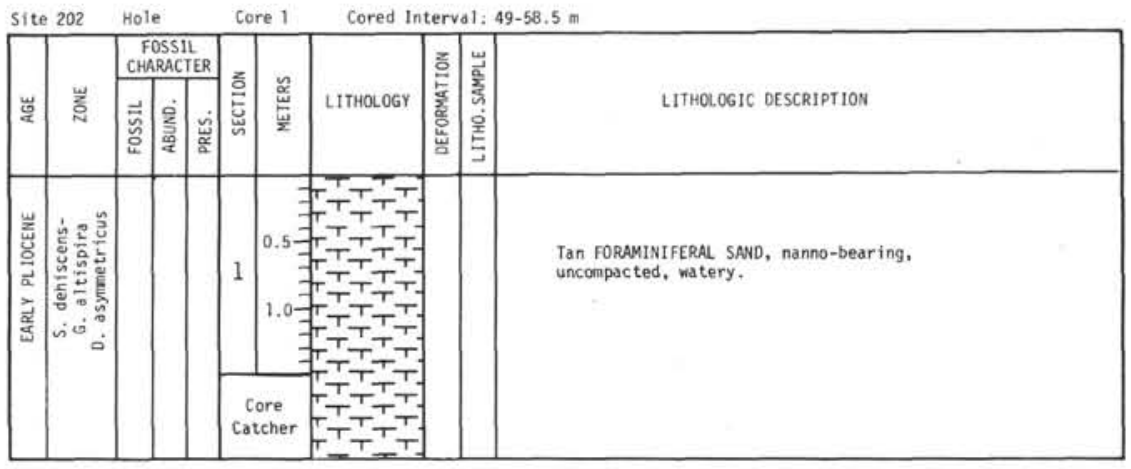

\begin{tabular}{|c|c|c|c|c|c|c|c|}
\hline Site & & Hole & & Core 2 & Cored in & nterval. & \\
\hline & & $\begin{array}{l}\text { FOSSI } \\
\text { FHARAC }\end{array}$ & & & & & \\
\hline 岁 & 言 & 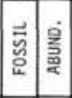 & 幽 & 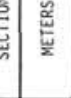 & LITHOLOGY & 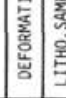 & LITHOLOGIC DESCRIPTION \\
\hline & & & & $\begin{array}{l}\text { Core } \\
\text { Catcher }\end{array}$ & $\begin{array}{l}T^{\top} T^{\top} \\
T^{\top} T^{\top}{ }^{\top}\end{array}$ & & White FORAMINIFERAL CHRLK. \\
\hline
\end{tabular}

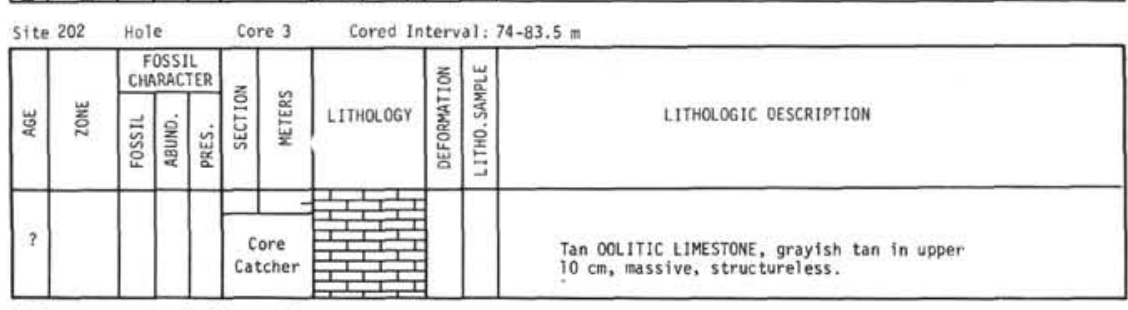

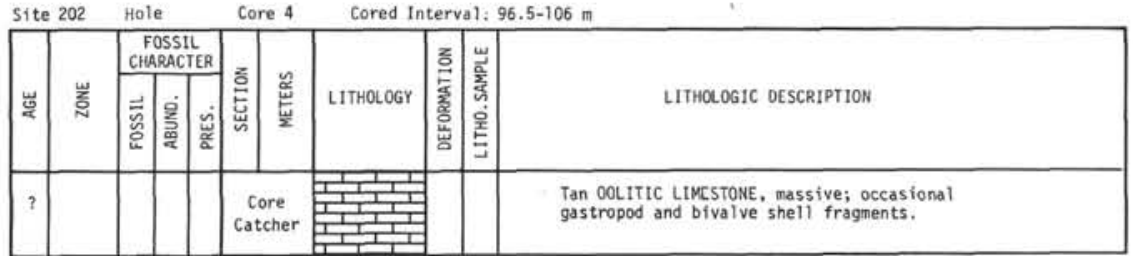

\begin{tabular}{|c|c|c|c|c|c|c|c|c|c|}
\hline \multicolumn{2}{|c|}{ Site 202} & \multicolumn{4}{|c|}{ Hole Core 5} & \multicolumn{4}{|c|}{ Cored Interval: $115.5-125 \mathrm{~m}$} \\
\hline \multirow[b]{2}{*}{ 崖 } & \multirow[b]{2}{*}{ 宸 } & \multicolumn{2}{|c|}{$\begin{array}{l}\text { FOSSIL } \\
\text { CHARACTER } \\
\end{array}$} & \multirow[b]{2}{*}{ 总 } & \multirow[b]{2}{*}{ 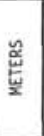 } & \multirow[b]{2}{*}{ LITHOLOGY } & \multirow{2}{*}{ 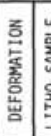 } & 崩 & \multirow[b]{2}{*}{ LITHOLOGIC OESCRIPTION } \\
\hline & & 苟 & 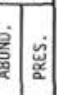 & & & & & 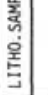 & \\
\hline$?$ & & & & \multicolumn{2}{|c|}{$\begin{array}{c}\text { Core } \\
\text { Catcher }\end{array}$} & & & & $\begin{array}{l}\text { White CALCAREOUS MLLK, consisting of a watery } \\
\text { suspension of calcite grains of unidentified } \\
\text { origin (possibly coral fragnents). }\end{array}$ \\
\hline \multicolumn{2}{|c|}{ Site 202} & \multicolumn{2}{|c|}{ Hole } & \multicolumn{2}{|c|}{ Core 6} & \multicolumn{4}{|c|}{ Cored Interval: $144-153.5 \mathrm{~m}$} \\
\hline \multirow{3}{*}{ | } & \multirow[b]{2}{*}{ 崖 } & & $\begin{array}{l}\text { SSIL } \\
\text { AACTER }\end{array}$ & \multicolumn{2}{|c|}{ z } & \multirow[b]{2}{*}{ LITHOLOGY } & \multirow{2}{*}{\multicolumn{2}{|c|}{ 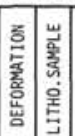 }} & \multirow[b]{2}{*}{ LITHOLOGIC DESCRIPTION } \\
\hline & & 慝 & 蜜安 & 总 & 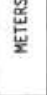 & & & & \\
\hline & & & & $\begin{array}{r}\text { co } \\
\text { Catc }\end{array}$ & $\begin{array}{l}\text { re } \\
\text { cher }\end{array}$ & & & & NO RECOVERY \\
\hline
\end{tabular}

Explanatory notes in Chapter 1 